\title{
ANALIZA SYSTEMU KLIMATYZACJI DLA KRYTYCH PLYWALNI Z WYKORZYSTANIEM POMPY CIEPLA DO OSUSZANIA POWIETRZA OBIEGOWEGO I WYMIENNIKA KRZYŻOWEGO
}

\begin{abstract}
Celem publikacji jest opracowanie metody projektowania parametrów powietrza w systemie klimatyzacji z wykorzystaniem pompy ciepła do osuszania powietrza obiegowego i wymiennika krzyżowego.
\end{abstract}

Słowa kluczowe: klimatyzacja, kryta pływalnia, powietrze recyrkulowane, pompa ciepła, osuszanie, krzyżowy wymiennik ciepła

\section{Wprowadzenie}

Przeprowadzono analizę systemu osuszania powietrza recyrkulowanego z wykorzystaniem sprężarkowej pompy ciepła oraz wymiennika krzyżowopłytowego dla hali krytej pływalni do odzysku ciepła [1]. W rozwiązaniu tym przy obciążeniach szczytowych (rozważając odparowanie wilgoci) zwiększa się ilość powietrza zewnętrznego do koniecznego minimum. Powietrze zewnętrzne po zmieszaniu się z powietrzem recyrkulowanym ogrzewa się, przepływając kolejno przez wymiennik krzyżowo-płytowy, skraplacz pompy ciepła, dodatkową nagrzewnicę, po czym trafia do pomieszczenia.

Przykładowo w hali krytej pływalni w okresie niekapielowym przy mniejszym zapotrzebowaniu na osuszanie powietrza urządzenie pracuje w trybie oszczędzania. Centrala funkcjonuje wówczas w układzie zamkniętym, osuszając powietrze obiegowe. Powietrze przepływa przez wymiennik krzyżowo-płytowy, następnie przez chłodnicę pompy ciepła, na powierzchni której wykrapla się wilgoć [1]. Schłodzone powietrze, przy odpowiednim ustawieniu przepustnicy, zawraca w bloku recyrkulacji, a następnie nagrzewa się do wymaganej temperatury, przepływając przez wymiennik krzyżowo-płytowy, skraplacz pompy ciepła i dodatkową nagrzewnicę powietrza (rys. 1.).

W okresie zimowym, przy niskich wartościach temperatury i pewnym udziale powietrza zewnętrznego, wymiennik krzyżowo-płytowy może w wystar- 
czającym stopniu osuszać powietrze obiegowe (tzn. powietrze wywiewane, którego część zostaje usunięta), bez konieczności włączania pompy ciepła [1]. Przy wyższych wartościach temperatury w okresie zimowym i przejściowym do osuszania powietrza recyrkulacyjnego wykorzystuje się również pompę ciepła we współpracy z wymiennikiem krzyżowo-płytowym [1].

Celem niniejszej pracy było określenie metody projektowania procesu przebiegu zmian stanu powietrza w systemie klimatyzacji z osuszaniem powietrza obiegowego, wykorzystując pompę ciepła i wymiennik krzyżowy ciepła. Na rysunku 2. został przedstawiony schemat takiego systemu wraz z pompą ciepła pracującą w cyklu woda-woda.

\section{Zasady teoretyczne projektowania systemu klimatyzacji}

Dane wyjściowe

1) parametry powietrza zewnętrznego według normy PN-76/B-03420 [2]:

- temperatura $-t_{Z}\left[{ }^{\circ} \mathrm{C}\right]$,

- wilgotność względna powietrza $-\varphi_{Z}[\%]$,

- entalpia właściwa powietrza $-i_{Z}[\mathrm{~kJ} / \mathrm{kg}]$,

- zawartość wilgoci $-x_{Z}[\mathrm{~g} / \mathrm{kg}]$,

2) parametry powietrza wewnętrznego:

- temperatura w pomieszczeniu $-t_{P}\left[{ }^{\circ} \mathrm{C}\right]$,

- wilgotność względna powietrza $-\varphi_{P}[\%]$,

3) parametry technologiczne:

- zyski ciepła całkowitego $-Q_{C}[\mathrm{~kW}]$ (określane dla danego obiektu),

- zyski ciepła jawnego - $Q_{J}[\mathrm{~kW}]$ (określane dla danego obiektu),

- zyski wilgoci - $W[\mathrm{~kg} / \mathrm{s}]$ (określane dla danego obiektu),

- niezbędny strumień objętościowy powietrza zewnętrznego ze względów higienicznych zalecany dla zapewnienia odczucia komfortu i świeżości $-G_{Z}\left[\mathrm{~m}^{3} / \mathrm{s}\right]$.

Budowanie przebiegu zmian stanu powietrza klimatyzacyjnego na wykresie $i-x$ powietrza wilgotnego rozpoczyna się od umiejscowienia punktu odpowiadającego parametrom powietrza zewnętrznego $Z\left(t_{Z}, \varphi_{Z}\right)$ (rys. 3.) (według PN-64/B-03420). Następnie ustala się parametry powietrza w pomieszczeniu, które mogą być podyktowane względami komfortu lub produkcji. Ustalone parametry powietrza w pomieszczeniu nanosi się na wykres $i$-x powietrza wilgotnego, otrzymując punkt $P$ o parametrach $\left(t_{P}, \varphi_{P}\right)$. W kolejnym kroku należy ustalić parametry powietrza nawiewanego. Temperatura tego powietrza może zależeć od dopuszczalnej różnicy wartości temperatury $\Delta t^{*}$ pomiędzy powietrzem nawiewanym a powietrzem w pomieszczeniu. Wartość tej różnicy temperatury zależy od miejsca usytuowania wylotów nawiewnych, przeznaczenia pomieszczenia, wysokości zysków ciepła itp. Stąd temperatura nawiewu $t_{N}$ wynosi: 


$$
t_{N}=t_{P}-\Delta t\left[{ }^{\circ} \mathrm{C}\right]
$$

W kolejnym kroku należy ustalić współczynnik kierunkowy przemiany stanu powietrza wilgotnego, który można wyznaczyć ze wzoru:

$$
\varepsilon=Q_{c} / W[\mathrm{~kJ} / \mathrm{kg}]
$$

Stan powietrza nawiewanego (punkt $N$ ) będzie zatem zależny od współczynnika kierunkowego $\varepsilon$ przechodzącego przez punkt $P$ i linii temperatury $t_{N}=$ const.

Odczytując $\mathrm{z}$ wykresu wielkość entalpii właściwej powietrza $\mathrm{w}$ tak wyznaczonym punkcie $N\left(i_{N}\right)$, można określić strumień objętościowy powietrza wentylacyjnego:

$$
G=\Delta Q_{C} /\left(\rho \cdot\left(i_{P}-i_{N}\right)\right)
$$

gdzie $\rho$-gęstość powietrza, $\rho=1,2 \mathrm{~kg} / \mathrm{m}^{3}$.

Następnie należy określić stan powietrza wywiewanego po wymienniku krzyżowo-płytowym (stan określony punktem $O$ ) i pompie ciepła (stan określony punktem $O^{\prime}$ ).

W kolejnym kroku wyznacza się punkty $O$ i $M$ określające stan powietrza odpowiednio po parowniku pompy ciepła (14, rys. 1.) i po zmieszaniu powietrza wywiewanego z zewnętrznym. Położenie tych punktów wyznacza się geometrycznie.

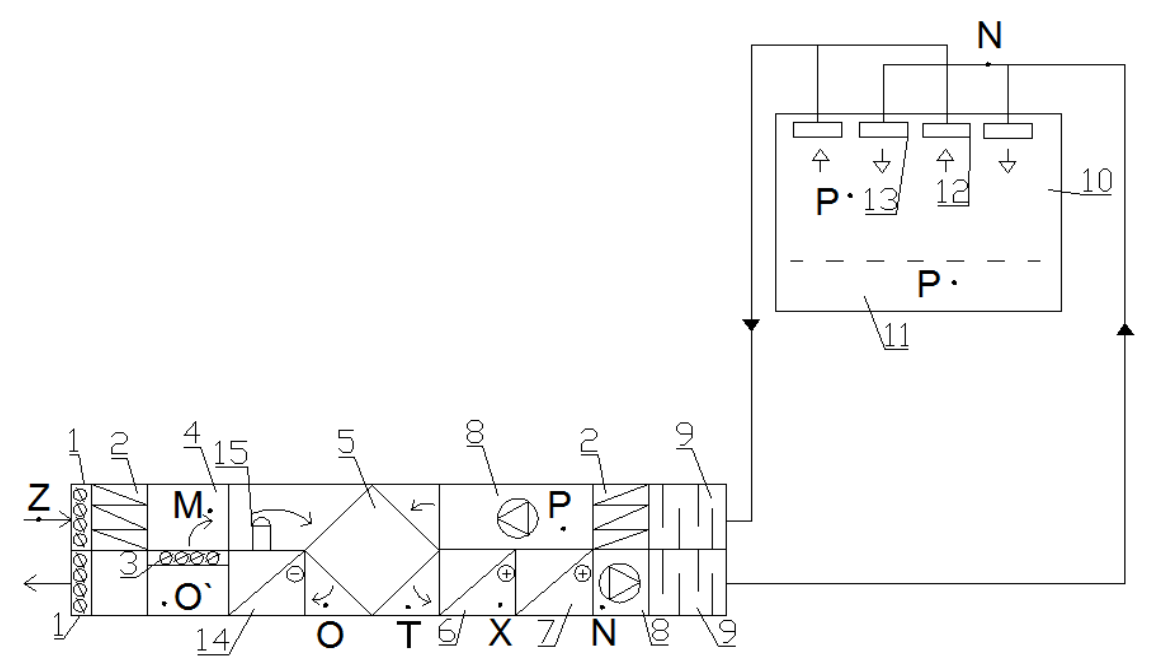

Rys. 1. Schemat systemu klimatyzacji pracującego w okresie zimowym z osuszaniem powietrza za pomocą pompy ciepła z odzyskiem ciepła na wymienniku krzyżowym dla hali krytej pływalni 
Na rysunku 1. przyjęto następujące oznaczenia: 1 - przepustnica powietrza zewnętrznego, 2 - filtr powietrza, 3 - przepustnica powietrza obiegowego, 4 - komora mieszania, 5 - wymiennik krzyżowo-płytowy do odzysku ciepła, 6 - skraplacz pompy ciepła, 7 - druga nagrzewnica powietrza, 8 - wentylator, 9 - thumik akustyczny, 10 - hala krytej pływalni, 11 - strefa przebywania ludzi, 12 - wylot powietrza, 13 - nawiew powietrza, 14 - parownik pompy ciepła, 15 - sprężarka pompy ciepła.

$\mathrm{Z}$ równania bilansu po wilgoci oblicza się zawartość wilgoci w punkcie $O$ $\left(x_{O^{\prime}}\right)$ :

$$
G_{Z} \cdot x_{Z}+G_{R E C} \cdot x_{O}=G \cdot x_{M}
$$

gdzie: $x_{M}$-zawartość wilgoci w punkcie $M, x_{M}=x_{N}[\mathrm{~g} / \mathrm{kg}]$,

$G_{R E C}-$ strumień objętościowy powietrza recyrkulowanego $\left[\mathrm{m}^{3} / \mathrm{h}\right]$,

$$
G_{R E C}=G-G_{Z}
$$

Stąd

$$
x_{O^{\prime}}=\left(G \cdot x_{M}-G_{Z} \cdot x_{Z}\right) / G_{R E C}
$$

Długość odcinka $Z M$ i $M O `$ należy dobrać tak, aby był spełniony warunek:

$$
G_{R E C} / G_{Z}=Z M / M O
$$

Należy jednak pamiętać, że punkty $M$ i $O$ `zostały ściśle określone przez parametry zawartości wilgoci w powietrzu, a mianowicie odpowiednio linii $x_{O}$ (wzór (5)) oraz $x_{M}\left(x_{M}=x_{N}\right)$. Za pomocą prostej łączy się punkty $Z$ i $O{ }^{`}$. Na prostej $Z O^{`}$ leży punkt $M$. Wykonując ruch wzdłuż linii $\varphi=90 \%$ do linii zawartości wilgoci $x_{P}=$ const, wyznacza się punkt $O$ (założenie [3]).

Następnie należy sporządzić obliczenia dotyczące wymiennika krzyżowego zgodnie $\mathrm{z}$ danymi zawartymi w katalogach producentów (obliczenia te wykonano w przykładzie). W tym celu należy określić temperaturę powietrza po wymienniku krzyżowym (temperatura $t_{T}$, stan powietrza punkt $T$ ):

$$
t_{T}=\eta \cdot\left(t_{P}-t_{O}\right)+t_{M}
$$

gdzie: $\eta$ - sprawność odzysku ciepła w krzyżowym wymienniku ciepła [\%], $t_{O^{\prime}}$ - temperatura w punkcie $O^{\prime}$ odczytana z rys. 3 . 
Wyznacza się moc chłodniczą pompy ciepła:

$$
Q_{p}=G \cdot \rho \cdot\left(i_{O}-i_{O}\right)
$$

gdzie $i_{O}, i_{O}$ - entalpia właściwa powietrza odpowiednio w punktach $O$ i $O$ odczytana $\mathrm{z}$ rys. $3 .[\mathrm{kJ} / \mathrm{kg}]$.

Należy przy tym pamiętać, że stan powietrza w punkcie $O$ jest zależny od konstrukcji i charakterystyki krzyżowo-płytowego wymiennika ciepła oraz warunków eksploatacji. W publikacji jest on określony warunkowo na przecięciu linii $x_{P}=$ const i $\varphi=90 \%$. W katalogach producentów krzyżowo-płytowych wymienników ciepła nie zawsze można odszukać danych o współczynnikach sprawności odzysku ciepła, a zwłaszcza informacji, czy jest to temperaturowy czy entalpijny współczynnik sprawności odzysku ciepła. Aby prawidłowo określić stan powietrza w punkcie $O$ (tj. czy następuje odbiór ciepła z wykropleniem wilgoci), trzeba dokładnie poznać charakterystyki krzyżowo-płytowego wymiennika ciepła. $Z$ katalogu producenta należy dobrać pompę ciepła na moc chłodniczą, a następnie odczytać moc cieplną pompy ciepła $Q_{S K R}$.

Ze względu na duże zapotrzebowanie na moc w tego typu obiektach zastosowano pompę ciepła pracującą w cyklu woda-woda, która jest w stanie zapewnić zapotrzebowanie na ciepło czy chłód. Na rysunku 2. przedstawiono schemat pracy pompy ciepła w systemie klimatyzacji pracującej w okresie zimowym z osuszaniem powietrza za pomoca pompy ciepła i z odzyskiem ciepła na wymienniku krzyżowym dla hali krytej pływalni.

Do określenia parametru powietrza po pierwszej nagrzewnicy $(6$, rys. 1.) - skraplaczu pompy ciepla korzysta się z zależności:

$$
Q_{S K R}=\rho \cdot c \cdot G \cdot\left(t_{X}-t_{T}\right)
$$

gdzie $t_{X}$ - temperatura w punkcie $X\left[{ }^{\circ} \mathrm{C}\right]$. Następnie wyznacza się temperaturę w punkcie $X\left(t_{X}\right)$ :

$$
t_{x}=\left[Q_{S K R} /(\rho \cdot c \cdot G)\right]+t_{T}
$$

gdzie $c$ - ciepło właściwe powietrza, $c_{p}=1,02 \mathrm{~kJ} /\left(\mathrm{kg} \cdot{ }^{\circ} \mathrm{C}\right)$. Temperatura ta pokaże, jaką moc musi mieć druga nagrzewnica (7, rys. 1.), aby dogrzać powietrze do wymaganej temperatury nawiewu. Moc omawianej nagrzewnicy określa się za pomocą wzoru:

$$
Q_{N}=\rho \cdot c \cdot G \cdot\left(t_{N}-t_{X}\right)
$$

Wyznaczenie obiegu rzeczywistego zmian stanu powietrza w instalacji jest możliwe tylko na początku eksploatacji systemu klimatyzacji. 


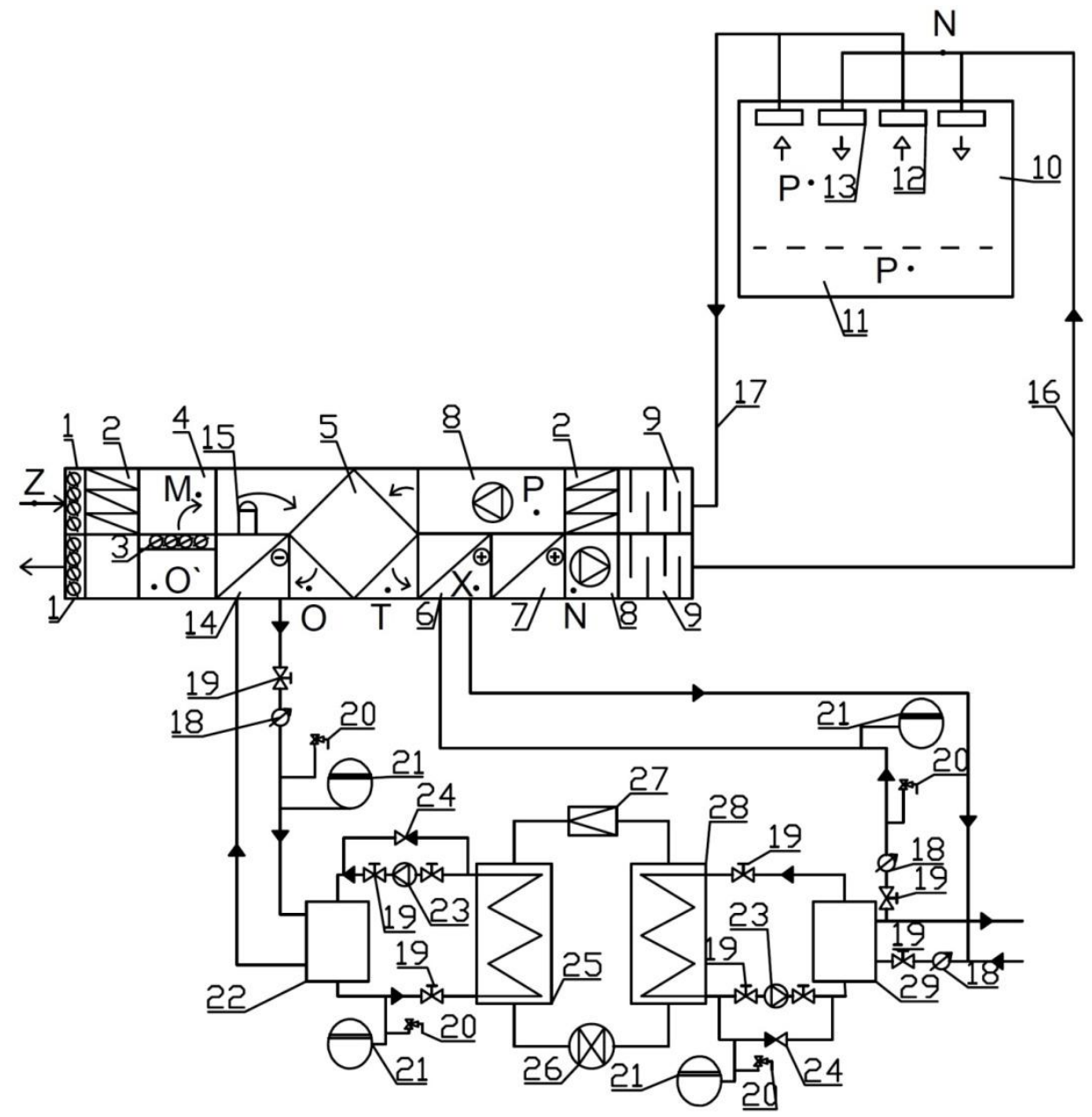

Rys. 2. Schemat systemu klimatyzacji pracującego w okresie zimowym z osuszaniem powietrza za pomocą pompy ciepła z odzyskiem ciepła na wymienniku krzyżowym dla hali krytej pływalni wraz ze schematem pompy ciepła pracującej w systemie woda-woda

Na rysunku 2. przyjęto następujące oznaczenia: 1-15 - jak na rys. 1., 16 - przewód zasilający, 17 - przewód powrotny, 18 - termomanometr, 19 - zawór odcinający, 20 - zawór bezpieczeństwa, 21 - naczynie wzbiorcze, 22 - zbiornik wody zimnej, 23 - pompa obiegowa, 24 - zawór zwrotny, 25 - parownik, 26 - zawór rozprężny, 27 - sprężarka, 28 - skraplacz, 29 - zbiornik wody gorącej. 


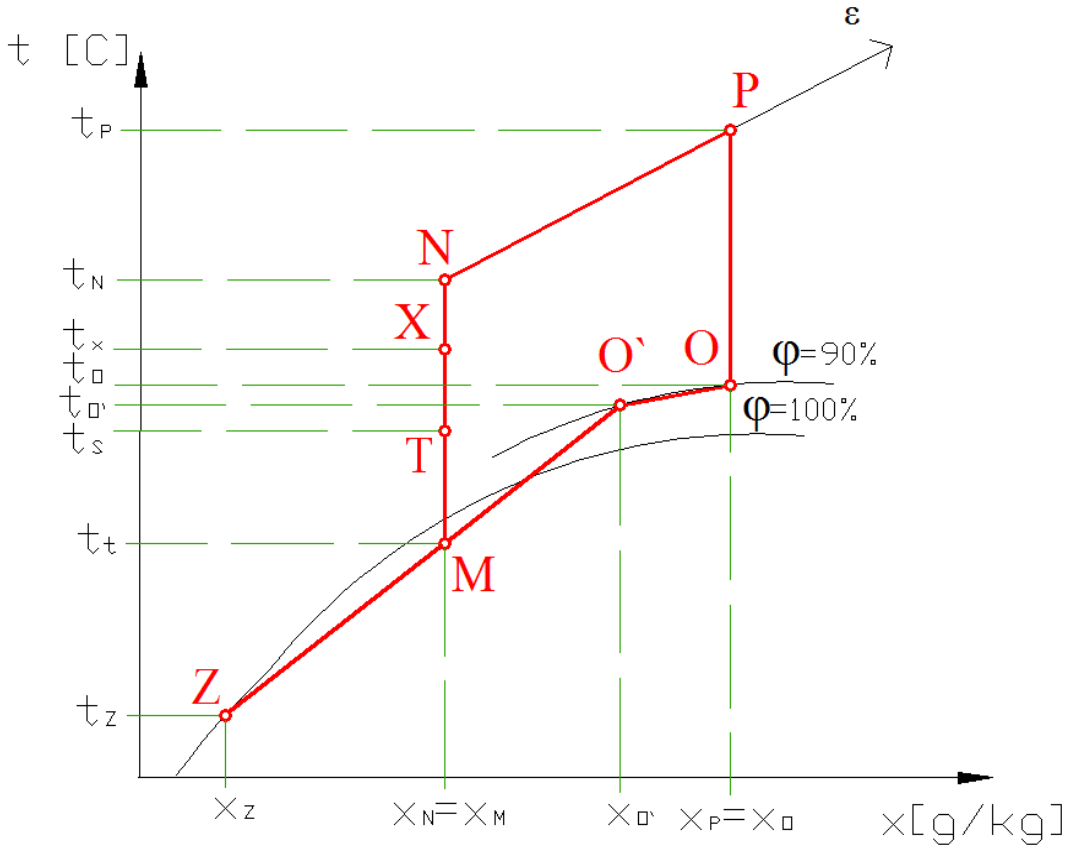

Rys. 3. Przebieg zmian stanu powietrza na wykresie $i-x$ powietrza wilgotnego dla okresu zimowego $\mathrm{z}$ osuszaniem powietrza obiegowego za pomocą pompy ciepła z odzyskiem ciepła na wymienniku krzyżowym

\section{Przykład obliczeniowy}

Dane wyjściowe: hala krytej pływalni

1) parametry powietrza zewnętrznego wg normy PN-76/B-03420 [2]:

- temperatura $-t_{Z}=-20^{\circ} \mathrm{C}$,

- wilgotność względna powietrza $-\varphi_{Z}=100 \%$,

2) parametry powietrza wewnętrznego:

- temperatura w pomieszczeniu $-t_{P}=30^{\circ} \mathrm{C}$,

- wilgotność względna $-\varphi_{P}=60 \%$,

3) parametry technologiczne:

- zyski ciepła całkowitego (oświetlenie itp.) $-Q_{C}=43,7 \mathrm{~kW}$,

- zyski wilgoci $-W=62,1 \mathrm{~kg} / \mathrm{h}=0,0173 \mathrm{~kg} / \mathrm{s}=62100 \mathrm{~g} / \mathrm{h}$,

- niezbędny strumień objętościowy powietrza zewnętrznego ze względów higienicznych zalecany dla zapewnienia odczucia komfortu i świeżości $G_{Z}=2400 \mathrm{~m}^{3} / \mathrm{h}=0,67 \mathrm{~m}^{3} / \mathrm{s}$. 
Budowanie wykresu przebiegu zmian stanu powietrza wentylacyjnego $i$ - $x$ powietrza wilgotnego rozpoczyna się od naniesienia punktu odpowiadającego parametrom powietrza zewnętrznego $Z\left(-20^{\circ} \mathrm{C}, 100 \%\right)$ oraz powietrza w hali krytej pływalni $P\left(30^{\circ} \mathrm{C}, 60 \%\right)$. Temperaturę nawiewu można określić ze wzoru (1), przy założeniu różnicy temperatury pomiędzy powietrzem nawiewanym a powietrzem w pomieszczeniu $\Delta t=0,5^{\circ} \mathrm{C}$ :

$$
t_{N}=30^{\circ} \mathrm{C}-0,5^{\circ} \mathrm{C}=29,5^{\circ} \mathrm{C} .
$$

Korzystając ze wzoru (2), oblicza się współczynnik kierunkowy $\varepsilon$ :

$$
\varepsilon=43,7 \mathrm{~kW} / 0,01725 \mathrm{~kg} / \mathrm{s}=2533 \mathrm{~kJ} / \mathrm{kg} .
$$

W ten sposób na przecięciu linii $\varepsilon$ oraz izotermy $t_{N}$ otrzymuje się punkt $N$. $\mathrm{Z}$ wykresu $i-x$ powietrza wilgotnego $\mathrm{z}$ rys. 4 . odczytuje się wartość entalpii $i_{N}=56 \mathrm{~kJ} / \mathrm{kg}$. Na podstawie tego wyznacza się strumień objętościowy powietrza wentylacyjnego $G$ (wzór (3)):

$$
\begin{aligned}
G & =43,7 \mathrm{~kW} /\left(1,2 \mathrm{~kg} / \mathrm{m}^{3} \cdot(72 \mathrm{~kJ} / \mathrm{kg}-56 \mathrm{~kJ} / \mathrm{kg})\right)=2,27 \mathrm{~m}^{3} / \mathrm{s}= \\
& =8193,8 \mathrm{~m}^{3} / \mathrm{h} .
\end{aligned}
$$

Przyjmuje się, że punkt $O$ leży na przedłużeniu prostej $x_{P}$ łączącej się z linią wilgotności względnej $\varphi=90 \%$. Wiedząc, że $x_{N}=x_{M}$ można ustalić zwartość wilgoci w punkcie $O$ '. Korzystając ze wzorów (5) i (6), oblicza się:

$$
\begin{aligned}
& G_{R E C}=8193,8 \mathrm{~m}^{3} / \mathrm{h}-2400 \mathrm{~m}^{3} / \mathrm{h}=5793,8 \mathrm{~m}^{3} / \mathrm{h}=1,6 \mathrm{~m}^{3} / \mathrm{s}, \\
& \begin{aligned}
x_{O} & =\left(8193,8 \mathrm{~m}^{3} / \mathrm{h} \cdot 10,2 \mathrm{~g} / \mathrm{kg}-2400 \mathrm{~m}^{3} / \mathrm{h} \cdot 0,8 \mathrm{~g} / \mathrm{kg}\right) / 5793,8 \mathrm{~m}^{3} / \mathrm{h}= \\
& =14,09 \mathrm{~g} / \mathrm{kg} .
\end{aligned}
\end{aligned}
$$

Następnie określa się zależność (7), która jest równa:

$5794 \mathrm{~m}^{3} / \mathrm{h} / 2400 \mathrm{~m}^{3} / \mathrm{h}=Z M / M O$,

stąd

$$
Z M / M O^{\prime}=2,41
$$

Znając stosunek odcinka $Z M$ do $M O^{\prime}$, można wyznaczyć geometrycznie położenie punktów $M$ i $O^{\prime}$, zgodnie z opisem zawartym w części teoretycznej. W kolejnym kroku należy określić temperaturę powietrza za wymiennikiem krzyżowym (punkty $T$ i $X$ ). 


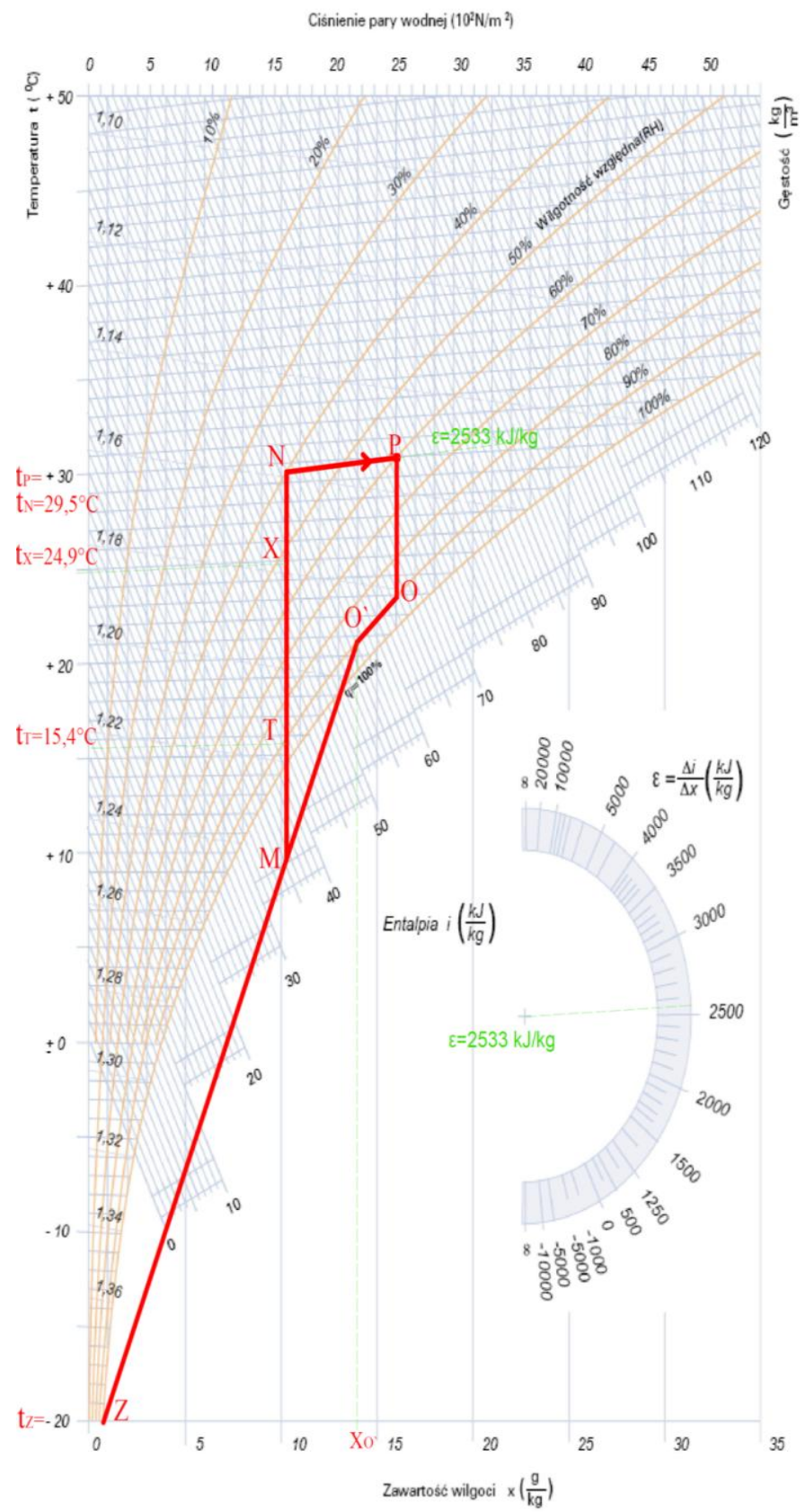

Rys. 4. Przebieg zmian stanu powietrza na wykresie $i-x$ powietrza wilgotnego w urządzeniach klimatyzacyjnych dla okresu zimowego z osuszaniem powietrza za pomocą pompy ciepła $z$ odzyskiem ciepła na wymienniku krzyżowym dla przykładu obliczeniowego 
Oblicza się temperaturę powietrza nawiewanego $t_{T}$ za wymiennikiem krzyżowym, korzystając ze wzoru (8) $(\eta=0,6$, katalog firmy VTS CLIMA [4]):

$$
t_{T}=0,60 \cdot(30-21)+10=15,4{ }^{\circ} \mathrm{C} .
$$

Temperaturę powietrza wywiewanego $t_{O}$ za wymiennikiem odczytuje się $\mathrm{z}$ wykresu $i$-x powietrza wilgotnego (rys. 3.) po geometrycznym wyznaczeniu położenia punktu $O$.

Wyznaczamy moc chłodniczą pompy ciepła, korzystając ze wzoru (9):

$$
Q_{p}=2,28 \mathrm{~m}^{3} / \mathrm{s} \cdot 1,2 \mathrm{~kg} / \mathrm{m}^{3} \cdot(64 \mathrm{~kJ} / \mathrm{kg}-56 \mathrm{~kJ} / \mathrm{kg})=21,9 \mathrm{~kW} .
$$

Dobrano wodną pompę ciepła W9W0E firmy HIBERNATUS o mocy cieplnej $Q_{S K R}=26,60 \mathrm{~kW}$ [5]. Temperaturę powietrza po pierwszej nagrzewnicy (6, rys. 1.) określa się ze wzoru (11):

$$
t_{X}=\left[26,60 /\left(1,2 \mathrm{~kg} / \mathrm{m}^{3} \cdot 1,02 \mathrm{~kJ} /\left(\mathrm{kg} \cdot{ }^{\circ} \mathrm{C}\right) \cdot 2,28 \mathrm{~m}^{3} / \mathrm{s}\right)\right]+15,4=24,9^{\circ} \mathrm{C} .
$$

Korzystając ze wzoru (12), określa się moc drugiej nagrzewnicy (7, rys. 2.):

$$
\begin{aligned}
Q_{p} & =2,27 \mathrm{~m}^{3} / \mathrm{s} \cdot 1,2 \mathrm{~kg} / \mathrm{m}^{3} \cdot 1,02 \mathrm{~kJ} /\left(\mathrm{kg} \cdot{ }^{\circ} \mathrm{C}\right) \cdot\left(29,5{ }^{\circ} \mathrm{C}-24,9{ }^{\circ} \mathrm{C}\right)= \\
& =12,8 \mathrm{~kW} .
\end{aligned}
$$

W przykładzie linia $Z K$ (rys. 4.) leży w strefie stanu powietrza wilgotnego, która charakteryzuje się wykropleniem wilgoci z powietrza, co może być zjawiskiem niepożądanym. W tym przypadku system klimatyzacji (na rys. 2.) należy uzupełnić nagrzewnicą wstępną (30, rys. 5.) i ogrzać strumień powietrza zewnętrznego w nagrzewnicy wstępnej (30) w procesie ZS (rys. 6.) do momentu zakończenia procesu mieszania strumienia powietrza (punkty $Z$ i $K$ ) w strefie niedopuszczającej wypadanie mgły.

Uwzględniając możliwość wykroplenia wilgoci $\mathrm{z}$ powietrza $\mathrm{w}$ procesie mieszania, przekształca się zasady budowy zmian stanu powietrza na wykresie $i$-x powietrza wilgotnego. Zakłada się, że np. punkt $M$ (rys. 6.) leży na przecięciu linii $x_{N}$ i $\varphi=90 \%$. Równanie $Z M / M O^{\prime}=2,41$ można zapisać $\mathrm{w}$ postaci $S M / M O^{\prime}=$ $=2,41$, gdzie punkt $S$ znajduje się na linii $x_{Z}=$ const.

Znając stosunek odcinka $S M$ do $M O^{\prime}$ wyznacza się w sposób geometryczny położenie punktów $S$ i $O^{\prime}$ (rys. 6.). Otrzymana prosta przechodzi przez punkt $M$.

Oblicza się temperaturę powietrza zewnętrznego $t_{T}$ za wymiennikiem krzyżowym, korzystając ze wzoru (8) $(\eta=0,6$, katalog firmy VTS CLIMA [4]) (z rys. 6. odczytano wartości: $t_{O^{\prime}}=21,7^{\circ} \mathrm{C}, t_{M}=16^{\circ} \mathrm{C}$ ):

$$
t_{T}=0,60 \cdot(30-21,7)+16=24,3^{\circ} \mathrm{C} .
$$




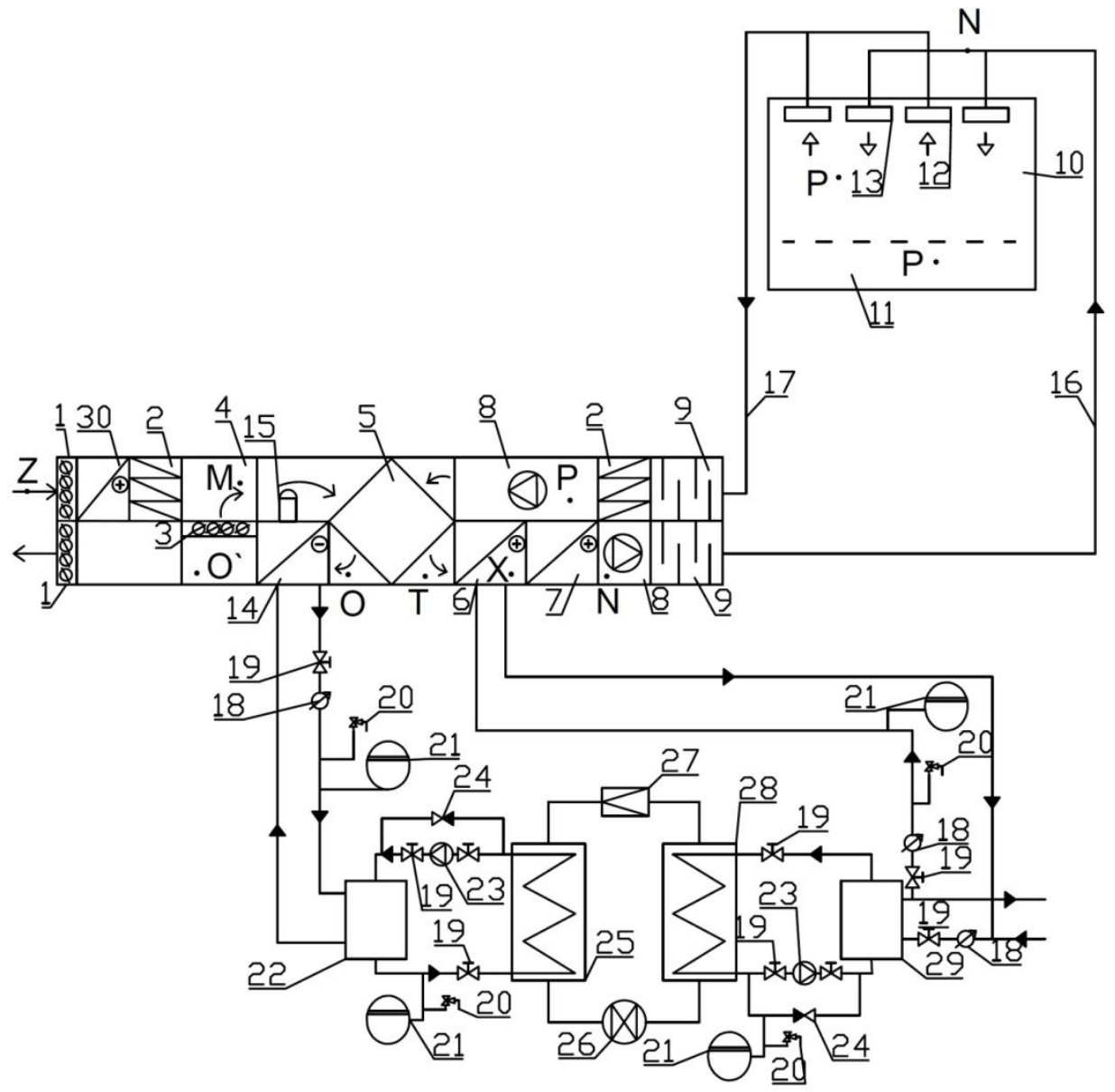

Rys. 5. Schemat systemu klimatyzacji pracującego w okresie zimowym z osuszaniem powietrza za pomoca pompy ciepła z odzyskiem ciepła na wymienniku krzyżowym dla hali krytej pływalni wraz ze schematem pompy ciepła pracującej w systemie woda-woda; 1-29 - oznaczenia jak na rys. $2 ., 30$ - nagrzewnica wstępna

Moc chłodniczą pompy ciepła wyznacza się ze wzoru (9):

$$
Q_{p}=2,27 \mathrm{~m}^{3} / \mathrm{s} \cdot 1,2 \mathrm{~kg} / \mathrm{m}^{3} \cdot(64 \mathrm{~kJ} / \mathrm{kg}-56 \mathrm{~kJ} / \mathrm{kg})=21,9 \mathrm{~kW} .
$$

Dobrano wodną pompę ciepła W9W0E firmy HIBERNATUS o mocy cieplnej $Q_{S K R}=26,60 \mathrm{~kW}$ [5]. Temperaturę powietrza po pierwszej nagrzewnicy (6, rys. 5.) określa się ze wzoru (11):

$$
t_{X}=\left[26,60 /\left(1,2 \mathrm{~kg} / \mathrm{m}^{3} \cdot 1,02 \mathrm{~kJ} /\left(\mathrm{kg} \cdot{ }^{\circ} \mathrm{C}\right) \cdot 2,28 \mathrm{~m}^{3} / \mathrm{s}\right)\right]+24,3=33,83^{\circ} \mathrm{C} .
$$




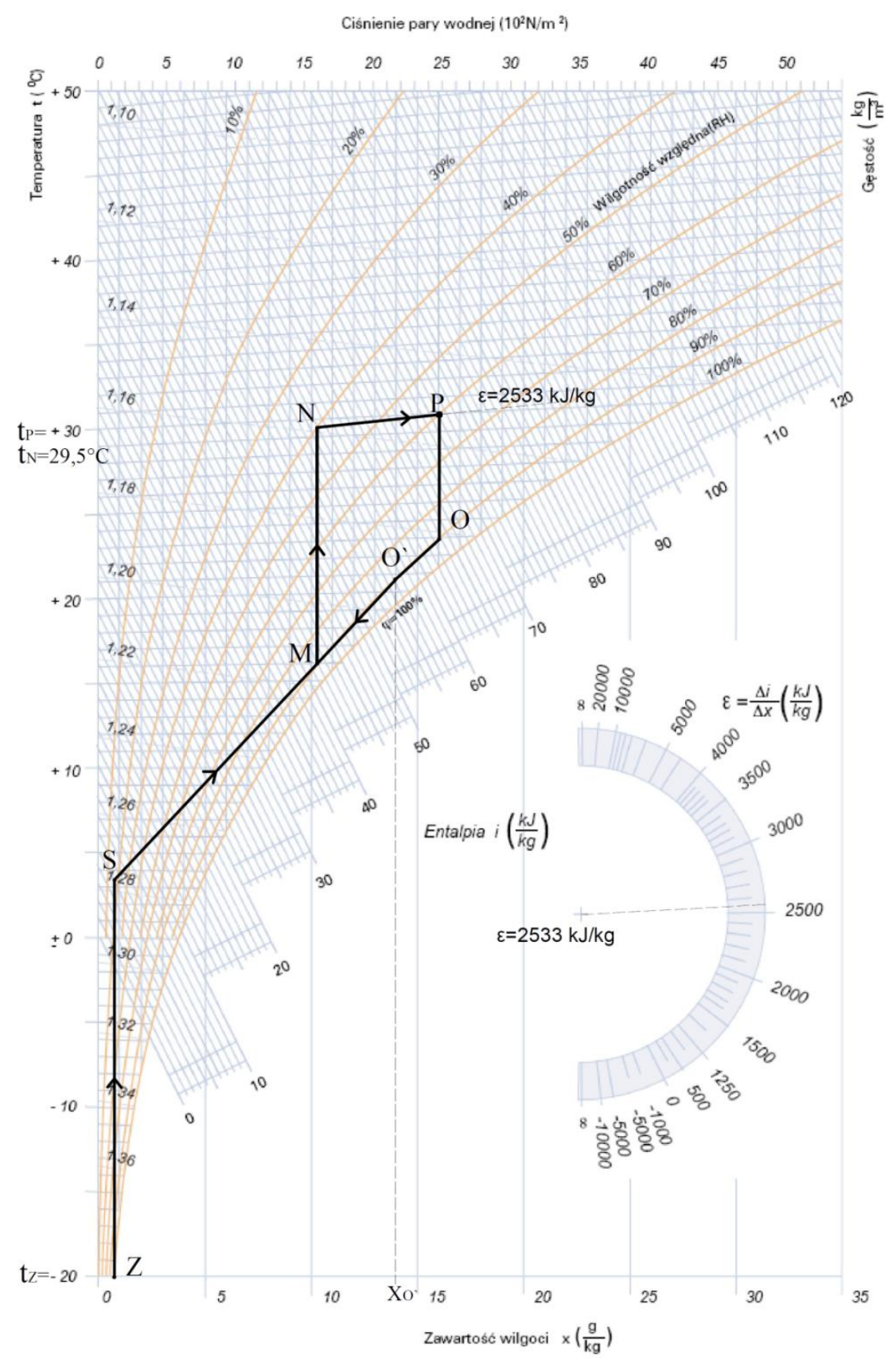

Rys. 6. Przebieg zmian stanu powietrza na wykresie $i-x$ powietrza wilgotnego w urządzeniach klimatyzacyjnych dla okresu zimowego z osuszaniem powietrza za pomocą pompy ciepła, z odzyskiem ciepła na wymienniku krzyżowym i z usunięciem w procesie mieszania strumieni powietrza wypadania mgły 
Otrzymany wynik świadczy o tym, że moc cieplna dobranej pompy ciepła jest niezbędna do obróbki nawiewanego powietrza. W danym przypadku trzeba określić możliwości całkowitego wykorzystania tej mocy. Ciepło może być skierowane do ogrzania zewnętrznego strumienia powietrza w procesie ZS (rys. 6.).

Moc cieplną $Q_{Z S}$ potrzebną do obróbki powietrza w procesie $Z S$ określa wzór:

$$
Q_{Z S}=\rho \cdot c \cdot G_{Z} \cdot\left(t_{S}-t_{Z}\right),
$$

gdzie temperaturę $t_{S}$ odczytuje się z rys. $6 ., t_{S}=3,5^{\circ} \mathrm{C}$.

Stąd $Q_{Z S}=0,67 \mathrm{~m}^{3} / \mathrm{s} \cdot 1,2 \mathrm{~kg} / \mathrm{m}^{3} \cdot 1,02 \mathrm{~kJ} /\left(\mathrm{kg} \cdot{ }^{\circ} \mathrm{C}\right) \cdot(3-(-20))^{\circ} \mathrm{C}=18,49 \mathrm{~kW}$. wzór:

Moc cieplną $Q_{T N}$ niezbędną do obróbki powietrza w procesie $T N$ określa

$$
\begin{aligned}
& Q_{T N}=\rho \cdot c \cdot G_{Z} \cdot\left(t_{N}-t_{T}\right), \\
& Q_{T N}=2,27 \mathrm{~m}^{3} / \mathrm{s} \cdot 1,2 \mathrm{~kg} / \mathrm{m}^{3} \cdot 1,02 \mathrm{~kJ} /\left(\mathrm{kg} \cdot{ }^{\circ} \mathrm{C}\right) \cdot(29,5-24,3)^{\circ} \mathrm{C}=14,17 \mathrm{~kW} .
\end{aligned}
$$

Z porównania wielkości $Q_{S K R}, Q_{Z S}$ oraz $Q_{T N}$ wynika, że różnicę $Q_{S K R}-Q_{T N}=$ $=26,60 \mathrm{~kW}-14,17 \mathrm{~kW}=12,43 \mathrm{~kW}$ można wykorzystać do ogrzania powietrza zewnętrznego przy mocy cieplnej 18,49 kW.

\section{Wnioski}

1. Opracowano metodę projektowania parametrów powietrza w systemie klimatyzacji z wykorzystaniem pompy ciepła i wymiennika krzyżowego do osuszania powietrza obiegowego w okresie zimowym.

2. Opracowano przykład projektowania systemu klimatyzacji z osuszaniem powietrza obiegowego, doborem pompy ciepła i wymiennika krzyżowego.

\section{Literatura}

[1] Jaskólski M., Micewicz Z.: Wentylacja i klimatyzacja hal krytych pływalni, JPPU MASTA, Gdańsk 2000.

[2] Norma PN-76/B-03420: Wentylacja i klimatyzacja. Parametry obliczeniowe powietrza zewnętrznego.

[3] Pisarev V.: Projektowanie systemów klimatyzacji jednoprzewodowej scentralizowanej, Oficyna Wydawnicza Politechniki Rzeszowskiej, Rzeszów 2009.

[4] Katalog firmy VTS Clima.

[5] Katalog firmy Hibernatus. 
ANALYSIS OF THE AIR CONDITIONING SYSTEM FOR SWIMMING FOOLS USING HEAT PUMP AND CROSS - FLOW HEAT EXCHANGER FOR DRYING RECIRCULATED AIR

S u m m a r y

The aim of the publication is to show method of designing the air parameters in air conditioning system for swimming foods using heat pump for drying recirculated air and cross - flow heat exchanger. This article show also an example calculation.

Keywords: air conditioning, indoor pool swimming, recirculated air, heat pump, drainage, crossflow heat exchanger

DOI: $10.7862 /$ rb.2012.9 